\title{
Pengambilan Keputusan Membeli Rumah Berdasarkan Belief dan Feng Shui
}

\section{Decision Making a House Based on Belief and Feng Shui}

\author{
Cicilia Rindi Antika* \\ Magister Psikologi Sains, Universitas Surabaya, Indonesia
}

Disubmit: 22 Desember 2020; Diproses: 31 Maret 2021; Diaccept: 01 September 2021; Dipublish: 02 Desember 2021 *Corresponding author: ciciliarindi@guru.pppkpetra.or.id

\begin{abstract}
Abstrak
Etnis Tionghoa merupakan etnis yang menyebar pada hampir seluruh wilayah di dunia, termasuk Indonesia. Salah satu etnis yang masih memegang teguh budaya mereka adalah Etnis Tionghoa. Salah satu budaya yang sangat lekat pada masyarakat Tionghoa yaitu Feng Shui. Peneliti melihat bahwa budaya Feng Shui masih banyak diterapkan oleh orang Tionghoa, termasuk orang Tionghoa yang bertempat tinggal di kota Surabaya. Salah satu penerapan ilmu Feng Shui dalam kehidupan yang ada ditengah masyarakat Tionghoa adalah dalam pengambilan keputusan membeli rumah. Keputusan membeli rumah merupakan sebuah keputusan yang kompleks yang memerlukan banyak pertimbangan. Selain faktor budaya Feng Shui, berdasarkan penelitian terdahulu terdapat aspek psikologis yang berpengaruh pada keputusan membeli rumah yaitu belief. Belief diyakini menjadi suatu faktor yang ikut mempengaruhi seseorang dalam pengambilan keputusan membeli rumah. Kajian literatur ini ingin melihat bagaimana pengaruh belief dan Feng Shui pada pengambilan keputusan membeli rumah. Kajian ini difokuskan pada orang Tionghoa yang bertempat tinggal di kota Surabaya.
\end{abstract}

Kata Kunci: Belief; Feng Shui; Pengambilan Keputusan

\begin{abstract}
Ethnic Chinese is an ethnicity that spreads in almost all regions of the world, including Indonesia. One of the ethnicities that still holds true to their culture is ethnic Chinese. One of the cultures that is very attached to Chinese society is Feng Shui. Researchers see that Feng Shui culture is still widely applied by Chinese people, including Chinese people who live in the city of Surabaya. One of the applications of Feng Shui science in life in chinese society is in the decision-making to buy a house. The decision to buy a house is a complex decision that requires a lot of consideration. In addition to Feng Shui cultural factors, based on previous research there are psychological aspects that affect the decision to buy a house, namely belief. Belief is believed to be a factor that influences a person in making the decision to buy a house. This literature review wants to see how belief and Feng Shui influence on decision-making to buy a home. This study focused on Chinese people residing in the city of Surabaya.
\end{abstract}

Keywords: Belief; Decision Making; Feng Shui

How to Cite: Antika, C.R. (2021), Pengambilan Keputusan Membeli Rumah Berdasarkan Belief dan Fengshui, Jurnal Diversita, 7 (2): 188-200. 


\section{PENDAHULUAN}

Manusia dan budaya adalah dua hal yang tidak dapat dipisahkan. Menurut Maryati, Kun dan Suryawati, (2001), kebudayaan adalah sebuah sarana hasil karya, sebuah rasa, serta cipta dari sebuah masyarakat. Sedangkan menurut Koentjaraningrat, kebudayaan merupakan sebuah keseluruhan sistem gagasan, sekumpulan tindakan, dan hasil-hasil karya manusia dalam sekumpulan kehidupan masyarakat yang dijadikan sebagai sebuah identitas manusia melalui belajar. Kebudayaan akan membawa sebuah konsep berpikir pada diri orang, menunjukkan sebuah identitas seseorang, menunjukkan pola perilaku tertentu yang khas, dan lain sebagainya. Kebudayaan dimiiki oleh orang-orang atau sekelompok masyarakat tertentu.

Etnis Tionghoa merupakan salah satu etnis sangat mudah ditemui hampir di seluruh bagian dunia sebab kita sendiri tahu bahwa mereka tesebar dan banyak yang melakukan migrasi ke negara lain termasuk Indonesia. Dalam kaitannya dengan kebudayaan, salah satu etnis yang memegang teguh budaya para leluhurnya adalah etnis Tionghoa, termasuk Etnis Tionghoa yang bertempat tinggal di negara Indonesia. Salah satu budaya yang sangat lekat dengan etnis ini yaitu mengenai Feng Shui. Hingga saat ini, masih banyak orang yang menerapkan prinsip ilmu Feng Shui dalam kehidupan seharihari mereka. Kajian ini berfokus pada penerapan prinsip ilmu Feng Shui pada etnis Tionghoa yang berada di kota Surabaya.

Darmayanti \& Sondang, (2014) menjelaskan Feng Shui adalah sebuah ilmu dan seni yang asal muasalnya dari kebudayaan Cina tradisional. Feng Shui juga bertujuan menciptakan serta membangun lingkungan yang harmonis bagi orang yang hidup didalamnya dengan menggunakan pendekatan metafisik dalam memperhitungkan energi (Chi/Qi). Sedangkan menurut Santosa (2018), Feng Shui adalah seni hidup harmonis dengan tanah dan perolehan keuntungan yang terbesar, kedamaian, dan kesejahteraan dari keberadaan suatu tempat yang benar pada waktu yang tepat. Lebih lanjut, Santosa (2018) menjelaskan Feng Shui adalah sebuah ilmu yang bisa dimanfaatkan untuk membantu memperbaiki kehidupan manusia dari empat energi buruk yang sifatnya merugikan yaitu huo hai, wu gui, liu sha, dan jue ming. Proses membantu dalam hal ini yang diwujudkan salah satunya dengan cara penataan lokasi rumah, pemilihan lokasi rumah, desain interior rumah, dan lain-lain.

Ada banyak sekali implikasi ilmu Feng Shui pada kehidupan masyarakat sehari-hari. Santosa (2018) membahas penerapan Feng Shui di banyak bidang misalnya Feng Shui untuk mengatur rumah, Feng Shui untuk menata kamar pengantin baru, Feng Shui untuk memupuk rasa cinta pasangan kekasih, Feng Shui untuk menjaga kesehatan anak, Feng Shui untuk merawat binatang peliharaan di rumah, dan masih banyak hal yang lainnya. Selain hal tersebut Feng Shui juga dapat diterapkan dalam pengambilan suatu keputusan penting misalnya membeli rumah. Ada banyak faktor yang mempengaruhi seseorang untuk membeli sebuah rumah.

Peneliti menemukan sebuah jurnal yang ditulis oleh Yu-Shu Peng, Hsin-Hua 
Hsiung (2012).Penelitian (Yu-Shu Peng, Hsin-Hua Hsiung (2012) mengkaji mengenai kepribadian berdasarkan big five, personal belief (superstition dan efikasi diri), dan perhatian pada Feng Shui dimana ketiga hal tersebut kaitkan dalam keputusan seseorang untuk membeli rumah. Penelitian yang dilakukan oleh YuShu Peng, Hsin-Hua Hsiung, (2012) memaparkan hasil bahwa terdapat hubungan yang positif antara kepribadian dan Feng Shui. Selain itu, penelitian ini juga memaparkan bahwa terdapat pula hubungan yang positif antara personal belief (superstition) dan Feng Shui.

Hingga saat ini, masih banyak orang Tionghoa yang percaya pada ilmu Feng Shui dan mereka masih menggunakannya dan mengimplikasikannya dalam membangun dan membeli rumah. Peneliti menemukan fenomena yang terjadi pada seseorang yang tinggal di Surabaya yaitu dimana orang tersebut kebingungan dalam mencari rumah untuk dibeli. Si A (inisial) tersebut mencari rumah yang menghadap ke arah barat sebab berdasarkan Feng Shui yang diyakininya, rumah yang menghadap barat tersebut sangat sesuai dengan kondisi dirinya dan diyakini akan membawa keberuntungan. Namun hingga saat ini, A belum menemukan rumah yang cocok sehingga keputusan untuk membeli rumah juga tertunda karena belum menemukan rumah yang cocok berdasarkan Feng Shui yang diyakininya. Seseorang yang berinisial B juga pernah menceritakan pengalamannya dalam mencari rumah di Surabaya. B mengatakan bahwa dia benarbenar selektif dalam melakukan pencarian rumah karena dia sangat memperhitungkan aspek Feng Shui dalam mencari rumah. Bahkan B siap membayar mahal demi mendapatkan rumah yang cocok berdasarkan Feng Shui. Dari beberapa hal tersebut, kita menjadi tahu bahwa Feng Shui dapat menjadi faktor penting bagi seseorang dalam pengambilan keputusan membeli rumah.

Topik pengaruh Feng Shui pada keputusan membeli rumah dirasa penting untuk dikaji sebab membeli sebuah rumah merupakan hal yang sangat kompleks dan merupakan sebuah keputusan yang perlu dipikirkan dampak jangka panjang ke depan. Membeli rumah tentu harus dipikirkan dengan matang, tidak boleh main-main karena kita tahu sendiri bahwa rumah tentunya adalah kebutuhan primer saat ini dimana setiap orang pasti memerlukan tempat untuk tinggal. Oleh sebab itu, kajian-kajian literatur ini ingin melihat dari sudut pandang psikologis mengenai faktor apa yang mempengaruhi keputusan orang dalam membeli sebuah rumah. Secara khusus, kajian literatur ini ingin mengaitkan keputusan membeli rumah, belief dan Feng Shui pada orang Tionghoa di Surabaya.

Saat ini, peneliti memang belum pernah menemukan penelitian yang secara khusus membahas mengenai kaitan langsung antara belief, Feng Shui dan pengambilan keputusan membeli rumah. Peneliti melihat hal ini sebagai peluang untuk membuat kajian yang baru yang diharapkan bisa membantu peneliti lainnya dalam menemukan sumber baru yang belum pernah ada sebelumnya. Oleh karena itu, peneliti akan mencoba mengkaji secara detail mengenai pengaruh belief dan Feng Shui pada pengambilan keputusan membeli rumah dengan fokus orang Tionghoa di Surabaya. Tujuan dari 
penelitian ini yaitu untuk menggambarkan budaya Feng Shui serta mengetahui pengaruh belief dan Feng Shui dalam keputusan membeli rumah pada orang Tionghoa di Surabaya. Selain itu, penelian ini memiki beberapa manfaat yaitu: memberikan gambaran mengenai Feng Shui, memberikan gambaran mengenai pengaruh belief dan Feng Shui pada orang yang memutuskan untuk membeli rumah, serta memberikan kajian literatur tambahan bagi penelitian selanjutnya.

Feng Shui adalah salah satu budaya yang berasal dari Cina dan sudah berlangsung secara turun temurun. Saat ini, budaya Feng Shui tidak hanya terdapat di Cina, namun mulai menyebar ke berbagai daerah, termasuk di Indonesia. Darmayanti \& Sondang, (2014) menjelaskan Feng Shui adalah sebuah ilmu dan seni yang asal muasalnya dari kebudayaan Cina tradisional. Feng Shui juga bertujuan menciptakan serta membangun lingkungan yang harmonis bagi orang yang hidup didalamnya dengan menggunakan pendekatan metafisik dalam memperhitungkan energi (Chi/Qi). Santosa (2018) menjelaskan Feng Shui adalah seni hidup harmonis dengan tanah dan perolehan keuntungan yang terbesar, kedamaian, dan kesejahteraan dari keberadaan suatu tempat yang benar pada waktu yang tepat. Lebih lanjut, Santosa, (2018) menjelaskan Feng Shui adalah sebuah ilmu yang bisa dipakai untuk membantu memperbaiki kehidupan manusia dari empat energi buruk yang sifatnya merugikan yaitu huo hai, wu gui, liu sha, dan jue ming.

Feng Shui dapat diimplikasikan pada banyak bidang kehidupan manusia. Seperti yang telah diungkapkan dibagian latar belakang masalah, Santosa (2018) membahas penerapan Feng Shui di banyak bidang misalnya Feng Shui untuk mengatur rumah, Feng Shui untuk menata kamar pengantin baru, Feng Shui untuk memupuk rasa cinta pasangan kekasih, Feng Shui untuk menjaga kesehatan anak, Feng Shui untuk merawat binatang peliharaan di rumah, dan masih banyak hal yang lainnya. Selain hal tersebut, Feng Shui juga dilakukan untuk pengambilan keputusan dalam membeli rumah.

Emmmons (dalam Yu-Shu Peng, Hsin-Hua Hsiung, 2012) menjelaskan bahwa Feng Shui dibentuk dari fenomena kebudayaan yang unik dari masyarakat Cina, dimana hal itu berpengaruh sangat dalam pada kehidupan sehari-hari masyarakat Cina. Feng Shui sangat bermanfaat bagi kehidupan salah satunya saat orang akan membuat keputusan penting dalam kehidupan mereka, mereka akan menggunakan Feng Shui sebagai pertimbangan dalam mengambil keputusan penting dalam hidup mereka, salah satunya adalah keputusan untuk membeli rumah. Tujuan penerapan Feng Shui dalam hidup yaitu supaya orang memiliki keberuntungan dan kenyamanan dalam hidup mereka, terutama dimana mereka tinggal. Selain hal tersebut, Feng Shui juga dianggap sebagai penyeimbang antara manusia dengan lingkungannya.

Tidak hanya terbatas pada tempat asalnya, Feng Shui sendiri merupakan unsur budaya yang masih banyak diterapkan di kehidupan sehari-hari, khususnya dalam masyarakat Tionghoa di Surabaya. Dalam latar belakang masalah, telah ditemukan fenomena pada 2 orang yang tinggal di Surabaya. Mereka masih mengimplikasikan ilmu Feng Shui dalam 
proses mereka membeli rumah. Selain itu terdapat penelitian dari Annita (2004) yang melakukan kajian pada pengaruh kepercayaan Feng Shui terhadap harga rumah di Citra Land, Surabaya Barat. Terdapat pula penelitian dari Hartanto (2007) yang mengkaji unsur Feng Shui digunakan sebagai salah satu pertimbangan seseorang dalam mengambil keputusan pembelian rumah di kawasan kota Surabaya Barat. Dari fenomena yang ada serta berdasarkan beberapa penelitian yang ditemukan, dapat disimpulkan bahwa fenomena Feng Shui masih banyak diterapkan pada masyarakat Tionghoa di Surabaya.

Penelitian ini mengkaji adanya kaitan antara Feng Shui dan belief. Teori mengenai belief dalam pembahasan ini akan ditinjau dari planned behavior theory. Planned behavior theory merupakan pengembangan dari theory of reasoned action. Theory of reasoned action menjelaskan bahwa intensi yang mendorong seseorang untuk melakukan suatu perilaku memiliki dua prediktor utama, yaitu attitude toward the behavior dan subjective norm. Selanjutnya dalam pengembangan dari teori ini yakni planned behavior theory menemukan adanya prediktor lain yang turut memengaruhi intensi seseorang untuk melakukan perilaku tertntu dengan memasukkan konsep perceived behavioral control. Pada akhirnya, didapatkan tiga prediktor utama yang memengaruhi intensi seseorang untuk melakukan suatu perilaku. Ajzen et al., (2005) menjelaskan ada tiga prediktor utama yang memengaruhi intensi seseorang untuk melakukan suatu perilaku yaitu persepsi tentang kontrol perilaku (perceived behavioral control), norma subyektif mengenai suatu perilaku (subjective norm), serta sikap terhadap suatu perilaku (attitude toward the behavior).

Ajzen et al., (2005) juga memaparkan bahwa sikap seseorang pada sebuah perilaku tertentu ditentukan berdasarkan keyakinan mengenai konsekuensi dari suatu perilaku atau secara singkat disebut dengan keyakinan perilaku (behavioral beliefs). Keyakinan ini terkait dengan penilaian subjektif individu pada dunia atau kehidupan yang ada disekitarnya serta mengenai pemahaman seseorang untuk mengenal lingkungan dan dirinya sendiri. Hal tersebut dilakukan dengan cara menghubungkan perilaku tertentu dengan berbagai manfaat atau kerugian yang mungkin didapatkan seseorang saat memilih melakukan atau tidak melakukannya perilaku tertentu. Keyakinan ini bisa memperkuat sikap terhadap perilaku itu apabila berdasarkan evaluasi atau penilaian yang dilakukan seseorang diperoleh hasil bahwa perilaku tertentu memberikan keuntungan baginya.

Ajzen et al., (2005) memaparkan mengenai norma subjektif. Norma subjektif adalah persepsi seseorang terhadap harapan dari orang-orang yang berpengaruh pada kehidupannya (significant others) mengenai dilakukan atau tidak dilakukannya perilaku tertentu. Hal ini disebut dengan norma subjektif karena memiliki sifat subjektif. Ajzen et al., (2005) menjelaskan pula bahwa norma subjektif dipengaruhi juga oleh keyakinan. Fungsi dari norma subjektif terjadi dari sebuah keyakinan individu yang diperoleh atas pandangan orang-orang lain terhadap objek sikap dan hal ini berhubungan dengan individu (normative belief). 
Sedangkan yang dimaksud dengan kontrol perilaku, Ajzen et al., (2005) menjelaskan bahwa control perilaku merupakan persepsi dari individu mengenai mudah atau sulitnya mewujudkan suatu perilaku tertentu. Dalam planned behavior theory, Ajzen et al., (2005) menjelaskan bahwa persepsi kontrol perilaku ditentukan oleh keyakinan individu mengenai ketersediaan sumberdaya. Sumber daya yang dimaksud dalam hal ini berupa kompetensi, kompatibelitas, kesempatan (control belief strength), dan peralatan yang mendukung atau menghambat perilaku yang diprediksi dan besarnya peran sumber daya (power of control factor) dalam mewujudkan perilaku tertentu. Perilaku tertentu ini berkaitan dengan semakin kuat keyakinan terhadap tersedianya sumberdaya dan kesempatan yang dimiliki individu. Semakin besar peran dari suatu sumberdaya, maka akn semakin kuat pula persepsi kontrol individu terhadap suatu perilaku.

Fishbein dan Ajzen (dikutip dari William Wong, 2012) menjelaskan bahwa planned behavior theory didasarkan atas pendekatan terhadap beliefs yang mendorong seseorang untuk melakukan perilaku tertentu. Pendekatan terhadap beliefs dilakukan dengan cara mengasosiasikan berbagai kualitas, atribut, dan karakteristik berdasarkan pada sebuah informasi yang dimiliki, lalu secara otomatis akan terbentuk intensi untuk berperilaku. Pendekatan yang dimaksud dalam planned behavior theory dikhususkan pada perilaku spesifik yang dilakukan individu dan bisa dipakai bagi semua perilaku secara umum Ajzen (dikutip dari William Wong, 2012). Ajzen et al., (2005) juga menambahkan, seberapa besar pengaruh subjective norm, perceived behavioral, serta attitude toward the behavior, kontrol terhadap suatu intensi untuk melakukan perilaku tertentu ditentukan oleh intensi berperilaku yang akan digambarkan. Besarnya pengaruh subjective norm, perceived behavioral control serta attitude toward the behavior kemungkinan juga berubah-ubah dari satu populasi ke populasi lainnya atau dari individu yang satu ke individu lainnya.

Pembahasan mengenai Feng Shui dan belief pada bagian sebelumnya akan dikaitkan pula dengan aspek pengambilan keputusan. Pengambilan keputusan menurut R. Terry (2006) adalah pemilihan perilaku yang didasarkan dari dua atau lebih alternatif yang ada. Menurut Stoner, (2006) pengambilan keputusan merupakan sebuah proses yang dipakai untuk memilih suatu tindakan dimana Tindakan tersebut akan digunakan sebagai cara pemecahan suatu masalah. Pengambilan keputusan sebagai kelanjutan dari pemecahan masalah memiliki fungsi sebagai permulaan atau dasar dari semua aktivitas manusia yang terarah dan sadar secara individual maupun secara kelompok baik organisasional ataupun institusional. Pengertian pengambilan keputusan yang lain dikemukakan oleh Atmosudirdjo (1982) yang memaparkan bahwa pengambilan keputusan merupakan suatu tahap akhir dari sebuah proses pemikiran atas suatu masalah dengan cara menjatuhkan pilihan pada alternatif yang ada. Proses pembuatan keputusan atau desicion making adalah sebuah proses memilih atau menentukan berbagai kemungkinan atas situasi-siuasi yang tidak 
pasti. Suharnan (2005) menjelaskan bahwa pembuatan keputusan terjadi dalam suatu situasi yang meminta seseorang harus: a) membuat estimasi mengenai frekuensi kejadian berdasarkan bukti-bukti yang terbatas, memilih salah satu diantara dua pilihan atau bahkan lebih atau, b) merancang sebuah prediksi kedepan. Dalam sebuah pengambilan keputusan atau decision making, keputusan yang dipilih adalah sebuah keputusan yang terbaik dari beberapa alternatif yang muncul sehingga tujuan yang diinginkan dari seseorang bisa tercapai.

Dalam decision making, ada beberapa faktor yang mempengaruhi pengambilan keputusan seseorang. Menurut Kotler (2003) beberapa faktor yang mempengaruhi pengambilan keputusan antara lain sebagai berikut:

Faktor psikologis terdiri atas keyakinan dan pendirian, pengetahuan, motivasi, serta persepsi.

Faktor sosial terdiri atas peran, status, keluarga serta kelompok acuan.

Faktor pribadi terdiri atas keadaan ekonomi, kepribadian dan konsep diri, usia, tahap siklus hidup, pekerjaan, serta gaya hidup,.

Faktor budaya yang terdiri atas sub budaya, kelas social, serta peran budaya.

Simon (dalam Luthans, 2006) menjelaskan ada tiga tahapan utama dalam proses pengambilan keputusan yaitu sebagai berikut:

Tahap Pemahaman (Inteligence Phace)

Di tahap ini, terdapat tahapan yang harus dilakukan yakni proses penelusuran dan identifikasi dari lingkup problem yang ada serta proses pengenalan atas masalah yang muncul. Data masukan yang diperoleh kemudian diproses dan diuji dalam rangka mengidentifikasikan suatu masalah.

\section{Tahap Perancangan (Design Phace)}

Tahap ini merupakan proses pengembangan dan pencarian alternatif atas sebuah tindakan atau solusi yang dapat diambil. Hal ini merupakan gambaran atas sebuah kejadian nyata yang disederhanakan. Oleh karena itu, diperlukan adanya suatu proses verifikasi dan validasi untuk mengetahui keakuratan model dalam meneliti masalah yang muncul.

\section{Tahap Pemilihan (Choice Phace)}

Dalam tahap ini dilakukan pemilihan dari berbagai alternatif solusi yang muncul pada tahap perencanaan supaya bisa ditentukan dengan memperhatikan kriteria-kriteria yang ada berdasarkan tujuan yang ingin diwujudkan.

\section{METODE PENELITIAN}

Penelitian ini adalah penelitian terkait dengan psikologi budaya. Metode penelitian yang digunakan dalam studi ini yaitu studi literatur (literature review). Penelitian diawali dengan menentukan topik penelitian, kemudian peneliti mencari jurnal, buku, bahan bacaan, dan bahan-bahan lainnya yang memiliki keterkaitan dengan topik yang diangkat. Setelah semua bahan yang terkait dengan topik terkumpul, peneliti melakukan analisis dari teori yang ada dan mengkaitkan dengan jurnal serta kondisi nyata yang ada dilapangan. Setelah itu peneliti menarik kesimpulan dari semua prosedur yang dilakukan. 


\section{HASIL DAN PEMBAHASAN}

Pada jurnal yang ditulis oleh Sia et al., (2018) memaparkan pengaruh Feng Shui pada intensi membeli rumah. Sia et al., (2018) menjelaskan bahwa orang membeli rumah memiliki dua tujuan. Pertama adalah untuk tempat tinggal dan yang kedua adalah untuk investasi. Apapun intensi yang dimiliki oleh seseorang, keputusan dalam membeli rumah adalah keputusan yang perlu mendapatkan banyak pertimbangan. Ada faktor yang satu faktor yang mempengaruhi pembelian sebuah rumah, salah satunya adalah Feng Shui. Orang yang memiliki kepercayaaan pada Feng Shui akan melihat bahwa rumah yang memiliki nilai Feng Shui yang baik akan mendatangkan keberuntungan bagi yang tinggal di dalamnya. Selain itu, mereka juga meyakini rumah tersebut akan memiliki nilai jual yang tinggi bila akan dijual kembali. Oleh karena itu, Feng Shui dapat menjadi salah satu faktor yang mendasari pemilihan sebuah rumah.

Orang yang memiliki kepercayaaan pada Feng Shui akan sangat selektif sekali dalam memilih sebuah rumah yang akan dia beli. Banyak faktor Feng Shui yang akan menjadi bahan pertimbangan dalam membeli sebuah rumah. Kong (2006) memaparkan beberapa hal dari Feng Shui yang dapat dijadikan pertimbangan dalam membeli rumah yaitu Feng Shui yang diaplikasikan pada eksterior bangunan, lokasi rumah, desain eksterior rumah, arah hadap rumah, dan lain-lain. Semua faktor tersebut akan menjadi dasar dalam melakukan pemilihan rumah untuk dibeli. Orang akan melihat kecocokan diri mereka dengan Feng Shui rumah yang akan dibeli. Bila mereka sudah menemukan rumah yang cocok dengan Feng Shui, mereka kemungkinan besar akan membelinya sebab dalam pandangan mereka, hal itu akan membawa keberuntungan dan kenyamanan dalam diri mereka. Bahkan, orang rela membayar mahal demi rumah yang memiliki Feng Shui yang cocok dengan keadaan diri orang tersebut.

Pada orang yang meyakini Feng Shui, terdapat unsur belief yang akan mempengaruhi seseorang dalam berperilaku teretentu, dalam hal ini terkait dengan pembelian rumah. Dalam kalimat lain, belief seseorang pada Feng Shui mendorongnya untuk melakukan pembelian rumah. Proses terbentuknya belief seseorang pada Feng Shui dapat dijelaskan melalui planned behavior theory. Planned behavior theory alaah pengembangan dari theory of reasoned action. Dalam planned behavior theory, ada tiga prediktor utama yang memengaruhi intensi seseorang dalam melakukan suatu perilaku, yaitu norma subyektif tentang suatu perilaku (subjective norm), sikap terhadap suatu perilaku (attitude toward the behavior), dan persepsi tentang kontrol perilaku (perceived behavioral control) (Ajzen et al., 2005)

Ajzen et al., (2005) menjelaskan bahwa sikap terhadap perilaku ini ditentukan berdasarkan pada keyakinan mengenai konsekuensi dari suatu perilaku atau yang secara singkat disebut keyakinan perilaku (behavioral beliefs). Keyakinan ini memiliki kaitan yang erta dengan pemahaman individu mengenai dirinya sendiri serta lingkungannya dan penilaian subjektif individu terhadap dunia sekitarnya. Hal tersebut dilakukan dengan cara menghubungkan perilaku tertentu dengan berbagai keuntungan atau 
kerugian yang mungkin diperoleh apabila individu melakukan atau tidak melakukan sebuah perilaku. Keyakinan ini akan memperkuat sikap terhadap perilaku tersebut bila berdasarkan evaluasi yang dilakukan individu, diperoleh hasil bahwa perilaku itu bisa memberikan banyak keuntungan baginya.

Pada mulanya, orang berusaha memahami dan belajar nilai-nilai serta pengetahuan dari konsep Feng Shui. Orang juga berusaha memahami diri mereka dan berusaha menanamkan konsep Feng Shui yang cocok untuk diterapkan pada dirinya. Dalam tahapan ini, orang menginternalisasikan apa yang telah mereka pelajari kemudian menanamkan dalam pola pikir mereka. Proses ini lama kelaman akan membentuk hal yang disebut belief pada Feng Shui. Belief yang dimiliki oleh seseorang mendorong munculnya penilaian subjektif pada objek tertentu, dalam hal ini berkaitan dengan rumah yang akan mereka pilih untuk dibeli. Penilaian yang subjektif ini artinya penilaian yang dilakukan oleh orang yang satu dengan yang lain bisa berbeda dalam mengkaji suatu rumah, cocok atau tidak dengan Feng Shui yang mereka miliki. Kadang orang A menilai sebuah rumah cocok dengan Feng Shui yang mereka miliki namun pada subjek $B$, sebuah rumah tidak cocok dengan Feng Shui diriya. Dari penilaian subjektif tersebut, orang akan mengevaluasi mengenai apa yang mereka yakini serta apa yang mereka putuskan, apakah membawa sebuah keuntungan bagi diri mereka atau malah sebaliknya. Bila membawa sebuah keuntungan, maka akan mendorong terciptanya sebuah perilaku, dalam hal ini keputusan membeli rumah. Orang akan membeli rumah saat mereka merasa rumah yang dipilih cocok untuk mereka dan berdasarkan Feng Shui, rumah tersebut dapat membawa keberuntungan dalam hidupnya. Sebaliknya, jika hasil penilaian pembelian rumah akan membawa kerugian dalam diri mereka, keputusan pembelian rumah tidak mungkin diwujudkan.

Norma subyektif mengenai suatu perilaku (subjective norm) bisa dijelaskan sebagai proses bagaimana suatu norma dapat mempengaruhi perilaku seseorang. Ajzen et al., (2005) memaparkan bahwa norma subjektif adalah persepsi dari seorang individu terhadap harapan dari orang-orang yang berpengaruh dalam hidup mereka (significant others) mengenai tidak dilakukan atau dilakukannya suatu perilaku tertentu. Dalam kaitanya dengan Feng Shui, dapat digambarkan dengan contoh sebagai berikut: Si A memiliki keluarga yang sangat mempercayai Feng Shui bahkan pada hampir semua keluarga besarnya percaya akan Feng Shui. Saat akan membeli sebuah rumah, keluarga si A memiliki kriteria dan pandangan bahwa si A harus membeli rumah berdasarkan Feng Shui. Bila melanggarnya, maka hidup si A bisa tidak bahagia. Oleh karena itu, akhirnya si A menuruti keluarganya yaitu membeli rumah berdasarkan keyakinan keluarganya. Hal itu dilakukan si A agar hidup si A bisa hidup bahagia, sesuai dengan keyakinan dari keluarga besarnya.

Sedangkan perceived behavioral control dapat dijelaskan sebagai proses merasakan kemampuan-kemampuan yang dapat membentuk sebuah perilaku. Ajzen et al., (2005) menjelaskan perceived behavioral control ditentukan oleh 
keyakinan individu yang terdiri atas kompatibelitas, peralatan, kompetensi, serta kesempatan yang mendukung atau menghambat perilaku yang akan diprediksi serta besarnya peran sumber daya tersebut dalam mewujudkan perilaku tertentu. Contohnya seseorang yang percaya akan Feng Shui akan membeli rumah berdasarkan pada keyakinan yang dimilikinya. Dia akan mencari banyak kesempatan untuk mencari rumah yang memenuhi kriteria yang diinginkan olehnya. Sebelum menemukan yang cocok, dia akan terus mencari kesempatan dan peluang mendapat rumah sesuai dengan Feng Shui yang ia yakini.

Belief seseorang pada Feng Shui akan mempengaruhi pengambilan keputusan dalam membeli rumah. R. Terry (2006) menjelaskan mengenai pengambilan keputusan yaitu pemilihan alternatif perilaku dari dua atau lebih alternatif yang ada. Sedangkan menurut Stoner (2006) pengambilan keputusan merupakan sebuah proses yang digunakan dalam memilih suatu tindakan sebagai langkah dari sebuah pemecahan masalah. Pengambilan keputusan sebagai kelanjutan dari cara pemecahan masalah memiliki fungsi yaitu sebagai pangkal dari segala aktivitas manusia yang terarah serta sadar baik secara kelompok maupun individual serta secara organisasional ataupun secara institusional.

Menurut Kotler (2003), pengambilan keputusan dipengaruhi oleh fakor-faktor seperti faktor pribadi, faktor budaya, faktor psikologis, dan faktor sosial. Dalam kajian ini faktor yang cocok untuk menggali pengaruh belief dan Feng Shui pada pengambilan keputusan membeli rumah adalah faktor budaya dan faktor psikologis. Feng Shui masuk dalam faktor budaya, sedangkan belief masuk dalam faktor psikologis. Kedua faktor ini saling berkaitan dan berhubungan sehingga menjadi faktor yang akhirnya mendorong seseorang untuk mengambil keputusan untuk membeli rumah. Orang yang memiliki belief pada Feng Shui berpendapat/berpandangan tertentu sebelum melakukan pembelian rumah. Dia akan melihat kecocokan dirinya dengan kondisi rumah berdasarkan Feng Shui. Setelah menemukan kecocokan, belief yang diyakini pada Feng Shui tesebut akan mendorong orang untuk melakukan pengambilan keputusan dalam membeli rumah.

Faktor-faktor lain yang bepengaruh pada pengambilan keputusan seperti dijelaskan oleh Kotler (2003) yaitu faktor sosial dan faktor pribadi. Faktor sosial misalnya adanya pengaruh dari masyarakat pada kehidupan seseorang. Contoh seseorang tinggal di lingkungan yang masyarakatnya banyak menganut Feng Shui, maka orang tersebut akan cenderung mengikuti pola yang ada pada lingkungannya yaitu percaya terhadap Feng Shui. Sedangkan faktor pribadi yaitu faktor yang asalnya dari dalam diri orang itu sendiri misalnya kepribadian yang dimiliki oleh orang tersebut. Misalnya si A merupakan orang yang yang terbuka akan adanya hal baru atau konsep yang berbeda dengan apa yang diyakini olehnya. Hal itu akan membuatnya mudah menerima keyakinan-keyakinan lain meskipun awalnya dia tak terlalu memahaminya.

Selain faktor, terdapat pula tahaptahap dalam pengambilan keputusan. Menurut Simon (dalam Luthans, 2006) ada 3 tahap dalam sebuah proses decision 
making (pengambilan keputusan) yaitu: tahap pemahaman, tahap perancangan, dan tahap pemilihan. Dalam kaiannya dengan pengambilan keputusan dengan pembelian rumah, tahap pertama yang dilalui yaitu pemahaman. Orang berusaha memahami keinginan dan harapan yang ada dalam diri mereka dalam mencari rumah untuk dibeli. Berdasarkan belief yang mereka miliki sebelumnya, mereka akan memasukkan banyak data misalnya lokasi rumah, keyamananan rumah, Feng Shui yang ada di rumah tersebut, kecocokan Feng Shui rumah dengan kepribadian mereka, dan lain-lain. Semua data tersebut kemudian diuji serta diproses untuk bisa melakukan identifikasi masalah apa saja yang mungkin muncul dalam proses pembelian rumah.

Tahap kedua yaitu tahap perancangan. Tahap ini adalah sebuah proses pengembangan serta menjadi sebuah bagian alternatif atas sebuah tindakan atau jalan keluar yang bisa diambil. Setelah berhasil memahami apa yang diinginkan dalam proses pembelian rumah, orang berusaha menetapkan alternati-alternatif pilihan pembelian rumah. Di tahap ini, orang akan melakukan klasifikasi rumah-rumah yang cocok dengan harapan mereka dan mengidetifikasi pro dan kontra dari masing-masing alternatif yang ada. Misalnya, A sudah berkeliling melihat-lihat perumahan di suatu daerah. Dari proses surveinya tersbut, dia akhirnya memperoleh 3 rumah yang cocok dengan keinginannya dan kemudian dia menjadikan 3 rumah tersebut sebagai alternatif-alternatif pilihan yang kemudian dalam tahap selanjutnya nanti akan dilihat pro dan kontra atas masing-masing rumah tersebut.

Terakhir adalah tahap pemilihan. Tahap ini merupakan langkah akhir pada sebuah proses decision making atau pengambilan keputusan. Pada tahap ini, yang dilakukan adalah pemilihan atas berbagai alternatif pemecahan masalah yang telah dimunculkan pada tahap sebelumnya yaitu perencanaan. Yang harus diperhatikan dalam tahap ini yaitu pemecahan masalah yang dipilih perlu memperhatikan kriteria-kriteria berdasarkan tujuan yang hendak dicapai. Dalam kaitannya membeli rumah, setelah orang menetapkan beberapa rumah yang masuk dalam kriteria mereka, orang akan memilih satu diantara banyaknya pilihan rumah yang ada. Dalam memutuskan rumah mana yang mereka pilih, mereka akan melihat pro dan kontra dari masingmasing rumah kemudian mereka akan memilih satu yang terbaik menurut belief mereka.

\section{SIMPULAN}

Penelitian ini termasuk penelitian psikologi budaya. Isi penelitian ini mengenai budaya masyarakat Tionghoa yaitu Feng Shui yang kemudian budaya Feng Shui tersebut dikaitkan dalam kajian psikologis yaitu belief dan pengambilan keputusan dalam membeli rumah. Penelitian mengenai topik ini masih sangat jarang dilakukan sehingga diharapkan hal ini memberikan kontribusi baru sebagai salah satu kajian alternatif yang bisa digunakan untuk membuat penelitian lainnya.

Di Surabaya, masih banyak orang etnis Tionghoa yang menerapkan budaya Feng Shui dalam pengambilan keputusan 
membeli rumah. Proses pengambilan keputusan dalam membeli rumah merupakan hal yang kompleks. Proses tersebut diawali dari pengetahuan dan pemahaan orang mengenai budaya Feng Shui. Pengetahuan dan pemahaman tersebut kemudian diinternalisasi oleh mereka menjadi sebuah belief. Belief akan membentuk pemahaman orang mengenai konsep tertentu, dalam hal ini membentuk belief pada Feng Shui. Belief pada Feng Shui ini kemudian menjadi dasar dari orang untuk melakukan tahap selanjutnya yaitu pengambilan keputusan untuk membeli rumah. Belief pada ilmu Feng Shui ini akan membawa mereka pada pandangan-pandangan khusus misalnya apakah sebuah rumah cocok untuk mereka, apakah rumah itu sesuai dengan Feng Shui mereka, apakah rumah itu nantinya akan membawa keberuntungan pada mereka, dan lain-lain. Dari pandangan itu, orang akan melakukan klasifikasi dan membuat beberapa alternatif pilihan mengenai rumah mana yang cocok untuk mereka. Dari alternatif tersebut, mereka akan memilih satu rumah yang paling cocok dengan keinginan mereka dan dipandang sebagai keputusan terbaik dari beberapa alternatif yang ada. Dari semua penjelasan yang ada, dapat disimpulkan bahwa terdapat pengaruh belief dan feng shui pada keputusan membeli rumah pada orang Tionghoa di Surabaya.

Penelitian ini sudah mencoba mengkaji pengaruh belief dan feng shui pada keputusan membeli rumah pada orang Tionghoa di Surabaya. Namun penelitian ini masih terdapat banyak kekurangan pada beberapa hal yaitu sistematika penulisan masih kurang terstruktur dengan baik, penelitian hanya terbatas pada fenomena yang muncul pada orang Tionghoa di Surabaya, serta kurangnya data empiris dari jurnal yang meneliti tentang pengaruh belief dan feng shui pada keputusan membeli rumah pada orang Tionghoa di Surabaya. Diharapkan peneliti lain yang ingin mengkaji topik yang sama dapat melakukan perbaikan pada struktur dan sistematika penulisan, memperluas lokasi penelitian yang tidak sebatas pada fenomena yang muncul pada orang Tionghoa di Surabaya, serta mencari data pendukung atau referensi berupa jurnal, buku, atau lainnya yang dapat mendukung topik yang akan diteliti.

\section{DAFTAR PUSTAKA}

Ajzen, I. I., Chen, L., Yang, X., Cruz, L. da, Suprapti, N. W. S., Yasa, N. N. K., Sulaeman, E. S., Murti, B., Setyawan, H., Rinawati, S., Ajzen, I. I., Coenders, M., Salehudin, I., Mukhlish, B. M., Uzaimi, A., Febriand Abdel, J., Armaidah, R., Machrus, H., Urip, P., ... Mahyarni, M. (2005). Attitudes, Personality \& Behavior. In Insan Media Psikologi. http://journal.unair.ac.id/INSAN@table_of_ content_8_volume12_nomori.html

Annita, S. (2004). Pengaruh kepercayaan feng shui terhadap harga rumah di Citraland Surabaya Barat. Universitas Kristen Petra Surabaya.

Atmosudirdjo, P. (1982). Administrasi dan Manajemen Umum. Ghalia Indonesia.

Darmayanti, T. E., \& Sondang, S. (2014). Pendekatan Feng Shui Dengan Metode Ba Zi Pada Desain Interior. Jurnal Waca Cipta Ruang, 1 (June). https://www.researchgate.net/publication/3 17425717_PENDEKATAN_FENG_SHUI_DE NGAN_METODE_BA_ZI_PADA_DESAIN_I NTERIOR

Hartanto. (2007). Unsur Feng Shui sebagai salah satu pertimbangan keputusan pembelian rumah di kawasan Surabaya Barat. Universitas Kristen Petra Surabaya.

Kong, S. M. dan L. L. C. (2006). Feng Shui dan Buying House. 22-27.

Kotler, P. (2003). Manajemen Pemasaran. Indeks kelompok Gramedia. 
Luthans, F. (2006). Perilaku Organisasi. PT. Andi.

Maryati, Kun dan Suryawati, J. (2001). Sosiologi untuk SMA dan MA kelas XI. Erlangga.

R. Terry, G. (2006). Prinsip-Prinsip Manajemen. Bumi Aksara.

Santosa, T. B. (2018). Buku Lengkap Shio dan Feng Shui. Laksana.

Sia, M. K., Yew, V. W. C., \& Siew, C. L. (2018). Influence of Feng Shui factors on house buying intention of Malaysian Chinese. Architectural Engineering and Design Management, 14(6), 427-439. https://doi.org/10.108o/17452007.2018.14666 84

Stoner, J. A. F. (2006). Manajemen, Jilid I, Edisi Keenam. Salemba Empat.

Suharnan. (2005). Psikologi Kognitif, Edisi Revisi. Skrikandi Ghalia.

William Wong. (2012). Planned Behavior Theory. https://wilyleo.wordpress.com/2012/03/05/ planned-behavior-theoryplanned-behaviortheory/

Yu-Shu Peng, Hsin-Hua Hsiung, and K.-H. C. (2012). The Level of Concern about Feng Shui in House Purchasing: The Impacts of Self-efficacy, Superstition, and the Big Five Personality Traits. Psychology \& Marketingsychology and Marketing, 29(Feng Shui), 519-530. https://doi.org/https://doi.org/10.1002/mar. 20539 